\title{
PERILAKU KEWIRAUSAHAAN PENGUSAHA MEBEL DI DESA SUCO KECAMATAN MUMBULSARI KABUPATEN JEMBER
}

\author{
Ayu Putri Septiana ${ }^{1}$, Sri Kantun ${ }^{1}$, Retna Ngesti Sedyati ${ }^{1}$ \\ ${ }^{1}$ Program Studi Pendidikan Ekonomi, Fakultas Keguruan dan Ilmu Pendidikan, Universitas Jember
}

\begin{abstract}
The research is research qualitative descriptive aims to understand entrepreneurship furniture behavior businesses in Suco at Mumbulsari Jember. The subject in question are entrepreneurs furniture in the village Suco number four people. Data collection method used covering the observation, interviews and documents. The method of analysis the data used was descriptive the method qualitative described data-data obtained from the results of the field implementation. Research conducted through observation and interview, the results about behavior the entrepreneurial Suco village in Mumbulsari District Jember. Furniture businessmen in running their business always faced with the risk of trade that must be faced that the point is not her ways goods over been sold so that suffered losses or fortunately diminished. Entrepreneurs furniture always very sure with capability owned. To be able to survive and develop their business, furniture entrepreneurs do creativity and innovation to products that been sold. Furniture businessmen also noticed if the it has its consumers want to buy or ordering products, so that is not left by customers and it has its consumers.
\end{abstract}

Keywords: Perilaku Kewirausahaan, mandiri, berani mengambil resiko, kerja keras, kreatif dan inovatif

\section{PENDAHULUAN}

Wirausaha berperan dalam pertumbuhan dan perkembangan infrastruktur jalan, serta barang dan jasa yang dibutuhkan manusia. Penyerapan tenaga kerja yang begitu banyak serta perputaran uang yang besar dan cepat tidak mungkin terjadi tanpa adanya peran wirausaha. Hal ini menunjukan bahwa peran wirausahawan sangat penting untuk pertumbuhan dan pembangunan ekonomi negara.Wirausahawan yang sukses adalah orang yang pandai memanfaatkan peluang. Peluang diciptakan dan dibangun dengan menggunakan ide-ide serta kreativitas kewirausahaan.

Seorang yang memiliki jiwa wirausahawan memiliki kredibilitas, kreativitas, serta berani memanfaatkan peluang-peluang yang ada. Berhasil atau tidaknya usaha ini sangat dipengaruhi oleh jiwa kewirausahaan dan kemampuan manajerial dari para pengusaha. Di Indonesia, peranan wirausaha dikaitkan dengan upaya pemerintah untuk mengatasi pengangguran, memperluas kesempatan kerja, memerangi kemiskinan dan pemerataan pendapatan.

Peranan wirausaha tidak diragukan lagi dalam menghadapi perkembangan ekonomi saat ini. Hal ini dikarenakan pertumbuhan perekonomian di suatu negara juga bergantung pada kehadiran dan keaktifan para wirausaha. Wirausaha yang dimaksud adalah para pengusaha yang mandiri yang memiliki kebebasan dalam memilih karier sesuai dengan bidang usaha yang diminatinya serta dapat menciptakan lapangan pekerjaan yang sebesar-besarnya. Wirausahawan yang sukses harus mempunyai perilaku yang baik, sehingga dapat menciptakan kemandirian pribadi untuk mencapai tujuan usahanya.

Jumlah penduduk di Indonesia yang terus bertambah dewasa ini merupakan suatu modal dasar pembangunan, namun di sisi lain besarnya jumlah penduduk tersebut akan menjadi suatu permasalahan jika tidak diimbangi dengan kemampuan pemerintah untuk menyediakan lapangan pekerjaan. Ketidakseimbangan ini menyebabkan banyaknya penduduk yang tidak 
terserap di sektor formal. Keterbatasan kemampuan pemerintah untuk menyediakan lapangan pekerjaan tersebut akan menyebabkan ketatnya persaingan bagi mereka untuk memasuki pekerjaan di sektor formal.

Masyarakat Indonesia menyadari bahwa dengan semakin tingginya pertumbuhan penduduk, dapat menyebabkan permasalahan kependudukan. Tingginya jumlah penduduk akan menjadi masalah besar pada bidang ketenagakerjaan, yang berakibat pada meningkatnya jumlah pengangguran yang ada di masyarakat. Hal tersebut tidak hanya terjadi di kota besar saja, tetapi juga melanda kota kecil bahkan pedesaan, seperti di Kecamatan Mumbulsari Kabupaten Jember.

Data yang diperoleh dari Badan Pusat Statistik (BPS) Kabupaten Jember mulai dari tahun 2010 sampai 2014, menunjukkan ketidakseimbangan antara jumlah pencari kerja dengan jumlah kesempatan kerja yang tersedia di Kecamatan Mumbulsari Kabupaten Jember. Perbandingan jumlah pencari kerja dengan kesempatan kerja selama kurun waktu tersebut dapat dilihat pada tabel di bawah ini.

Tabel 1.1 Jumlah penduduk dan jumlah kesempatan kerja di Kecamatan Mumbulsari

Kabupaten Jember pada Tahun 2010 Sampai Tahun 2014

\begin{tabular}{|c|c|c|}
\hline Tahun & Jumlah Pencari Kerja & Kesempatan Kerja \\
\hline 2010 & 1.764 & 190 \\
\hline 2011 & 2.050 & 182 \\
\hline 2012 & 2.266 & 180 \\
\hline 2013 & 2.967 & 178 \\
\hline 2014 & 3.156 & 175 \\
\hline
\end{tabular}

Sumber: Badan Pusat Statistik Kabupaten Jember tahun 2014.

Berdasarkan tabel 1.1 tersebut dapat dilihat bahwa jumlah pencari kerja di Kecamatan Mumbulsari Kabupaten Jember semakin tahun semakin meningkat, sedangkan kesempatan kerja semakin menurun sehingga jumlah pengangguran dari tahun ke tahun juga semakin meningkat. Untuk dapat bersaing memasuki dunia kerja masyarakat harus memiliki bekal keterampilan yang memadai. Mereka perlu memiliki alternatif lain jika mereka tidak dapat memasuki lowongan kerja yang disediakan oleh pemerintah daerah setempat, begitu halnya di Desa Suco Kecamatan Mumbulsari Kabupaten Jember.

Untuk menanggulangi hal tersebut, salah satu yang patut dijadikan pertimbangan utama oleh masyarakat yaitu mengenai keterampilan dan keahlian dalam memasuki dunia kerja. Hal ini disebabkan di Desa Suco Kecamatan Mumbulsari Kabupaten Jember mayoritas masyarakatnya masih memiliki pendidikan yang rendah, sehingga untuk memasuki dunia kerja formal sangat sulit. Oleh karena itulah banyak di antara masyarakat Desa Suco Kecamatan Mumbulsari Kabupaten Jember yang meningkatkan kemampuan dan keahlian dalam bekerja untuk membuka suatu usaha sendiri. Salah satu jenis pekerjaan yang termasuk sektor informal adalah wirausahawan yang didalamnya terdapat usaha mebel, usaha rumah makan, usaha jahit, tukang cukur, penjual makanan keliling, dan lain-lain. Para wirausahawan seperti ini banyak dijumpai di pinggir-pinggir jalan, seperti di daerah Desa Suco Kecamatan Mumbulsari Jember. Keputusan mereka memilih menjadi wirausahawan dikarenakan memenuhi kebutuhan masyarakat sekitar. 
Menurut Joseph Shcumpeter dalam Alma (2006:22) Entreprenuer atau wirausaha adalah orang yang mendobrak sistem ekonomi yang ada dengan memperkenalkan barang dan jasa yang baru, dengan menciptakan bentuk organisasi baru atau mengolah bahan baku baru. Seorang wirausaha adalah orang yang melihat adanya peluang kemudian menciptakan sebuah organisasi untuk menciptakan, memanfaatkan peluang tersebut. Menurut Kasmir (2007:16) Wirausaha adalah orang yang berjiwa berani mengambil resiko untuk membuka usaha dalam berbagai kesempatan. Sedangkan menurut Danuhadimedjo (1998:50) wirausaha merupakan suatu kreativitas, dan sikap tindak/perilaku manusia yang mampu mengkoordinir sumber alam, tenaga manusia dan peralatannya menjadi benda-benda jasa ekonomi.

Selanjutnya Suryana (2001:23) mengatakan perilaku secara umum membicarakan tentang aspek mental dan respon fisik yang ada di dalam jiwa seorang individu untuk bereaksi terhadap lingkungan fisiknya. Sehingga dengan adanya perilaku ini dapat membuat seseorang untuk menentukan langkah dan perbuatan seseorang. Munandar (2005:41) berpendapat bahwa perilaku berkaitan dengan motif dan mendasari tingkah laku seseorang. Sementara yang dimaksud perilaku adalah respon individu terhadap frekuensi fisik, durasi dan tujuan baik disadari maupun tidak. Perilaku merupakan kumpulan berbagai faktor yang saling berinteraksi. Sering tidak disadari bahwa interaksi tersebut sangat kompleks sehingga kadang-kadang kita tidak sempat memikirkan penyebab seseorang menerapkan perilaku tertentu (Nurhayati, 2000:27)

Perilaku kewirausahaan sangat penting dalam berwirausaha. Astamoen (2005:45) menyebutkan bahwa hal selalu dihadapi oleh enterpreneur adalah resiko berupa kegagalankegagalan, hendaknya rasa takut tersebut dapat dikelola dengan sebaik-baiknya dan penuh keberanian agar bisa menghasilkan keuntungan dan hal-hal positif. Seringkali orang ragu untuk membuka usaha, karena belum apa-apa sudah takut rugi. Oleh karena itulah tidak semua orang dapat memiliki perilaku berwirausaha. Seseorang yang memiliki perilaku kewirausahaan akan merasa senang atau suka melakukan berbagai tindakan yang berhubungan dengan wirausaha. Hal ini dikarenakan perilaku kewirausahaan tersebut bersifat pribadi, sehingga perilaku kewirausahaan antar masyarakat berbeda walaupun mereka sama-sama memiliki suatu usaha sendiri. Sesuai dengan permasalahan di atas, maka peneliti tertarik untuk melakukan penelitian dengan judul "Perilaku Kewirausahaan Pengusaha Mebel Di Desa Suco Kecamatan Mumbulsari Kabupaten Jember”.

\section{METODE PENELITIAN}

Penelitian ini merupakan penelitian dengan pendekatan penelitian kualitatif. Menurut Straus and Corbin (dalam Hotman, 2002:1) penelitian kualitatif adalah jenis penelitian yang menghasilkan penemuan-penemuan yang tidak dapat dicapai dengan menggunakan prosedurprosedur statistik atau dengan cara kuantifikasi lainnya. Penelitian kualitatif dapat digunakan untuk meneliti kehidupan masyarakat, sejarah, tingkah laku, funsionalisasi organisasi, pergerakan- pergerakan sosial, atau hubungan kekerabatan. Penelitian dilakukan dengan beberapa langkah yaitu: (1) reduksi data, (2) penyajian data dan (3) pengambilan keputusan atau verifikasi.

Metode penentuan lokasi penelitian menggunakan metode purposive yaitu tempat penelitian ditentukan dengan sengaja oleh peneliti yang secara khusus dikaitkan dengan tujuan 
penelitian ini. Lokasi dalam penelitian ini yaitu di Desa Suco Kecamatan Mumbulsari Kabupaten Jember.

Metode pengumpulan data yang digunakan terdiri dari metode: observasi, wawancara, dan dokumen. Analisis data yang akan digunakan mengacu pada pendekatan metode analisis data kualitatif karena data yang dikumpulkan bersifat kualitatif. Data-data yang diperoleh melalui berbagai metode pada penelitian ini, baik data dari hasil studi kepustakaan maupun data dari hasil penelitian langsung di lapangan akan dianalisis dengan pendekatan kualitatif yang menggambarkan dan mendeskripsikan perilaku wirausaha masyarakat di Desa Suco Kecamatan Mumbulsari Kabupaten Jember. Selanjutnya Untuk menguji kebenaran data dalam penelitian ini, maka peneliti menggunakan teknik triangulasi. Teknik triangulasi menurut Moleong (2001: 170) adalah pemeriksaan data dengan memanfaatkan sesuatu diluar data tersebut sebagai pembanding terhadap data yang diperoleh. Jadi, data yang diperoleh dari berbagai sumber informasi tentang perilaku wirausaha, mandiri, berani menanggung resiko, kemauan untuk bekerja keras, serta pemikiran kreatif dan inovatif, kemudian dicek dengan cara membandingkan antara informasi dari berbagai sumber yang berbeda.

\section{HASIL DAN PEMBAHASAN}

\section{Hasil Penelitian}

Hasil penelitian yang dipaparkan oleh peneliti meliputi perilaku kemandirian, berani menanggung resiko, bekerja keras, serta kreatif dan inovatif pengusaha mebel di desa Suco Kecamatan Mumbulsari Kabupaten Jember.

Untuk dapat memperoleh keuntungan dan kesuksesan, seorang wirausaha harus dapat berspekulasi dan berani menanggung resiko. Hal ini disebabkan karena, semakin besar resiko yang mereka tanggung, maka keuntungan yang akan mereka peroleh juga akan semakin besar. Jadi seorang wirausaha harus siap terhadap resiko yang akan mereka hadapi untuk memperoleh keuntungan yang mereka inginkan. Begitu juga dengan para pemilik mebel di Desa Suco Kecamatan Mumbulsari Kabupaten Jember, dimana para pemilik mebel tersebut berani melakukan beberapa upaya yang penuh dengan resiko guna terus menjalankan usaha yang dimiliki dan meningkatkan usaha yang dimiliki tersebut.

Berikut merupakan hasil wawancara yang dilakukan peneliti dengan salah satu pemilik mebel di Desa Suco Kecamatan Mumbulsari Kabupaten Jember yang menjadi informan inti dalam penelitian ini.

"Menjadi pengusaha rintangan yang sering di hadapi tidak lakunya barang dan banyak pesaing yang membuat saya ragu, tapi saya yakin dan tidak pernah putus asa. Dan sekarang alhamdulillah sudah banyak pelanggan mbak." ( $\left.\mathrm{SH}, 54^{\mathrm{Th}}\right)$.

Bapak Sofyan Sahuri juga pernah mengalami penurunan pelanggan ketika memutuskan untuk tidak menyediakan bahan baku kayu yang berkualitas. Namun lama kelamaan dinilai Bapak Sofyan Sahuri kurang menguntungkan.

"pernah saya kekurangan bahan baku kayu mbak, saat itu harga kayu sangat mahal jadi harga mebelnya juga mahal. Kemudian saya tawarkan kayu yang kualitasnya rendah dan saya akan membuat sebagus mungkin. Tetapi pelanggan tidak mau karena tidak sesuai dengan keinginan. Akhirnya saya menawarkan kayu yang berkualitas sesuai 
dengan permintaan dengan harga yang cukup mahal mbak. Dan akhirnya pelanggan menyetuji mbak”. (SH, 54 ${ }^{\mathrm{Th}}$ )

Keputusan tidak menyediakan bahan baku kayu yang berkualitas merupakan peluang untuk memperoleh keuntungan yang lebih besar. Namun jika tidak sesuai dengan permintaan pelanggan, maka akan ditinggalkan pelanggan. Hal ini dikarenakan pelanggan mencari produk mebel yang lebih tahan lama sesuai dengan kualitasnya.

Berikut merupakan penjelasan tambahan dari salah satu pemilik mebel yang menjadi informan inti dalam penelitian ini

"Usaha sendiri seperti mebel ini memang penuh dengan resiko mbak, seperti ketika melakukan pengiriman barang dan terjadi kerusakan, saya selaku pihak mebel harus bersedia untuk menggantinya, selain itu saya juga harus dapat melakukan pinjaman kredit untuk terus dapat meningkatkan usaha yang saya miliki tersebut mbak" (AH, 49 $\left.{ }^{\mathrm{Th}}\right)$.

Seseorang jika hendak menjadi seorang wirausaha, mereka harus bisa mempersiapkan segala sesuatu untuk menanggulangi resiko yang akan mereka hadapi. Hal ini dikerenakan dalam membuka suatu usaha sendiri pastilah terdapat resiko yang akan menghambat mereka dalam menjalankan usahanya, baik dalam bentuk waktu maupun dana. Adanya keberanian para pemilik mebel dalam menanggung resiko dari usaha yang dimiliki tersebut dapat menjadikan usaha mebel berjalan dengan lancar serta mudah dalam meningkatkan usaha yang dimiliki tersebut.

“.................saya berani mengambil resiko karna saya yakin mbak kalau setiap masalah ada jalan keluarnya. Menjadi pengusaha memang harus berani mbak mengambil resiko. Pernah saya menaikkan harga mebel saya mbak untuk kayu yang berkualitas sedang. Yang awalnya Rp 2.000.000 menjadi Rp 2.500.000. Tapi lama kelamaan pelanggan banyak yang tidak mau mbak. Akhirya saya kembalikan lagi harga ke awal mbak." (AH, 49 $\left.{ }^{\mathrm{Th}}\right)$.

Bapak Ahmad Hadi memutuskan untuk menaikkan harga mebel yang seula Rp 2.000.000 menjadi Rp 2.500.000 untuk meningkatkan keuntungan. Namun hal itu di rasa pelanggan semakin sedikit, karena disesuaikan dengan kemampuan beli pelanggan. Dan akhirnya Bapak Ahmad Hadi mengembalikan harga seperti semula agar pelanggannya tidak lari ke mebel lainnya. Hal tersebut juga dijelaskan oleh salah satu pemilik mebel yang menjadi informan inti dalam penelitian ini.

"Saat itu saya kekurangan modal mbak untuk tetap bertahan. Kemudian saya meminjam uang ke bank yang jumlah sangat banyak mbak dengan jangka waktu 5 tahun mbak. Awalnya saya ragu mbak untuk mengambil kredit karena jumlahnya sangat besar. Tapi saya yakin kalau saya bisa mencicil tiap bulannya beserta bunganya mbak. Lalu di pertengahan mebel saya sepi pelanggan mbak karena saat itu harga kayu mahal jadi kemampuan beli pelanggan kurang mbak, terus cicilan bank saya juga terlambat mbak dan harus membayar denda mbak" (WP, 50"h).

Begitu juga dengan para pemilik mebel di Desa Suco Kecamatan Mumbulsari Kabupaten Jember, dimana para pemilik mebel tersebut terus berupaya mengerahkan ide kreatif dan inovasi terhadap segala produk yang dijual pada mebel mereka. 
Berikut merupakan hasil wawancara yang dilakukan peneliti dengan salah satu pemilik mebel di Desa Suco Kecamatan Mumbulsari Kabupaten Jember yang menjadi informan inti dalam penelitian ini.

"Untuk dapat terus meningkatkan usaha saya melakukan beberapa upaya mbak, yaitu dengan membuat model mebel yang unik-unik mbak. Selain saya membuat bentuk yang menjadi lebih menarik, saya menambahkan beberapa ukiran pada almari yang berbagan dari kayu, saya juga membuat furniture yang berbahan dasar rotan mbak. Membuat mebel yang unik saya tidak mencontoh milik orang lain mbak tapi saya berimajinasi sendiri mbak." ( $\left.\mathrm{SH}, 54^{\mathrm{Th}}\right)$.

Dari penjelasan tersebut dapat dilihat bahwa Untuk dapat terus meningkatkan usaha yang dimiliki serta untuk dapat menghadapi persaingan dengan mebel lain, maka pemilik mebel melakukan beberapa upaya, salah satunya yaitu dengan melakukan beberapa kreatifitas dan inovasi dalam produk yang saya hasilkan. Dalam hal ini dapat dilihat bahwa pemilik mebel berupaya membuat bentuk yang menjadi lebih menarik, seperti menambahkan beberapa ukiran pada almari yang berbagan dari kayu, saya juga membuat furniture yang berbahan dasar rotan. Hal tersebut juga sesuai dengan penjelasa dari salah satu pemilik mebel yang menjadi informan inti dalam penelitian ini, adalah sebagai berikut.

"Saya melakukan berbagai upaya untuk dapat terus menarik minat konsumen mbak, salah satunya yaitu dengan membuat beberapa produk furniture yang unik, seperti bentuk almari yang didesain dengan memberikan beberapa pola dan warna, dan saya juga mebuat tempat duduk untuk anak usia kurang dari 3 tahun yang aman, serta beberapa furniture khusus anak-anak" (AH, 49 $\left.{ }^{\mathrm{Th}}\right)$.

Hal tersebut juga sesuai dengan penjelasan dari para pemilik mebel lain yang juga menjadi informan inti dalam penelitian ini yaitu sebagai berikut:

“. saya membuat beberapa beberapa produk yang berbeda dengan mebel lainnya mbak, yaitu saya membuat meja dari akar pohon yang besar mbak, seperti jati dan mahoni, dan itu banyak sekali masyarakat yang tertarik mbak" (WP, $50^{\mathrm{Th}}$ ).

Ide kreatif dan inovatif merupakan hal yang sangat penting yang harus terus dikembangkan oleh para pengusaha terutama bagi pemilik usaha mebel seperti dalam penelitian ini. Hal ini dikarenakan dengan dengan adanya ide kreatif dan inovatif tersebut, maka usaha mebel tersebut dapat terus berjalan dan dapat terus berkembang secara konsisten sesuai dengan tujuan dari perusahaan tersebut.

\section{Pembahasan}

Berdasarkan penelitian yang dilakukan dapat diketahui bahwa perilaku kewirausahaan pengusaha mebel di Desa Suco Kecamatan Mumbulsari Kabupaten Jember meliputi kemandirian, berani menanggung resiko, bekerja keras, serta memiliki ide yang krestif dan inovatif.

Adanya adanya sikap kemandirian/tidak ketergantungan terhadap pihak lain yang dilakukan oleh beberapa pemilik mebel di Desa Suco Kecamatan Mumbulsari Kabupaten Jember yang menjadi informan inti dalam penelitian ini tetap mengutamakan konsumen dalam pemenuhan kebutuhan furniture. Jadi, bagi seorang wirausaha, sikap kemandirian/ketidaktergantungan kepada orang lain sangat penting dalam menjalankan usaha 
yang dimiliki tersebut. Selama seorang berwirausaha dalam menjalankan usahanya selalu bersumber pada fasilitas yang diberikan pada orang lain, maka ia tidak akan pernah menjadi wiraswastawan yang sejati meskipun bergelimang kemewahan. Oleh karena itu, sifat kemandirian itu sangat penting dalam berwirausaha karena untuk menjadi seorang wirausaha yang kreatif dan tidak lagi memiliki atasan kecuali dirinya sendiri. Selanjutnya Hakim (1998:32) mengemukakan bahwa seorang wiraswasta tidak diperintah orang lain dan menjadi bos setidaknya bagi dirinya sendiri serta tidak akan pernah mengalami pemutusan hubungan kerja. Jadi dengan memiliki sifat kemandirian ini, seorang wirausaha tidak lagi bergantung pada orang lain dan dapat mengendalikan apa yang mereka lakukan.

Para pemilik usaha mebel melakukan pinjaman kredit pada bank untuk dapat terus meningkatkan usaha mebel yang dimiliki tersebut. Selaim itu, mereka juga melakukan berbagai upaya untuk memperoleh bahan baku yang berkualitas. Tentu saja dalam menjalankan usaha mebel ini tidak akan luput dari permasalahan, dan para pemilik usaha mebel tersebut berani dalam menanggung resiko tersebut. Seperti dalam melakukan pengiriman terjadi kerusakan barang, maka pemilik mebel juga sanggup menggantinya. Selain itu, pemilik usaha mebel sering memberikan potongan harga bagi produk lama yang masih belum laku.

Untuk dapat memperoleh keuntungan dan kesuksesan, seorang wirausaha dapat berspekulasi dan berani menanggung resiko. Hal ini disebabkan karena, semakin besar resiko yang mereka tanggung, maka keuntungan yang akan mereka peroleh juga akan semakin besar. Seorang wirausaha berani menghadapi resiko, semakin besar resiko yang dihadapinya, semakin besar pula kesempatan untuk meraih keuntungan. Jadi seorang wirausaha siap terhadap resiko yang akan mereka hadapi untuk memperoleh keuntungan yang mereka inginkan.

Para pemilik mebel di Desa Suco Kematan Mumbulsari Kabupaten Jember tidak hanya melakukan kerja keras dalam hal menjalankan usaha mulai dari meyiapkan bahan baku hingga proses produksi, akan tetapi para pemilik tersebut juga melakukan berbagai upaya dalam mempromosikan produk kepada konsumen yaitu seperti pembuatan spanduk. Kasmir (2007:27) menjelaskan benak seorang pengusaha selalu memikirkan kemajuan usahanya, dan ide-ide baru selalu mendorongnya untuk bekerja keras merealisasikannya, sehingga seorang wirausaha harus terus memiliki kemauan untuk bekerja keras untuk terus memajukan usahanya.

Kemauan untuk bekerja keras merupakan suatu kemauan kuat untuk melakukan suatu tindakan secara bersungguh-sungguh untuk mencapai tujuan yang diharapkan.Oleh sebab itu, adanya kemauan bekerja keras maka seseorang dapat meraih suatu hasil yang maksimal dari usaha wirausaha sehingga dapat mencapai tujuan yang telah ditentukan. Para wiraswastawan menyadari bahwa dengan adanya usaha keras, maka keberhasilan akan dicapai. Jadi, kemauan untuk bekerja keras merupakan suatu kunci untuk memperoleh kemajuan dan keberhasilan dalam usaha wirausaha.

Berdasarkan penelitian yang telah dilakukan dapat diketahui bahwa untuk dapat terus meningkatkan usaha yang dimiliki serta untuk dapat menghadapi persaingan dengan mebel lain, maka pemilik mebel melakukan beberapa upaya, salah satunya yaitu dengan melakukan beberapa kreatifitas dan inovasi dalam produk yang saya hasilkan. Dalam hal ini dapat dilihat bahwa pemilik mebel berupaya membuat bentuk yang menjadi lebih menarik, seperti menambahkan beberapa ukiran pada almari yang berbagan dari kayu, saya juga membuat furniture yang berbahan dasar rotan. 
Ide kreatif dan inovatif merupakan hal yang sangat penting yang terus dikembangkan oleh para pengusaha terutama bagi pemilik usaha mebel seperti dalam penelitian ini. Hal ini dikarenakan dengan dengan adanya ide kreatif dan inovatif tersebut, maka usaha mebel tersebut dapat terus berjalan dan dapat terus berkembang secara konsisten sesuai dengan tujuan dari perusahaan tersebut. Dimana kreatif dan inovatif tersebut selalu berpedoman pada kebutuhan dan kepentingan konsumen akan perlengkatan furniture yang mereka butuhkan. Seorang wirausaha tidak akan pernah puas dengan ide-idenya dan selalu berpikir kreatif dan inovatif untuk menciptakan maupun mengkombinasikan hal-hal yang baru yang sebelumnya belum pernah ada. Hal ini dimaksudkan untuk dapat menarik minat konsumen, serta untuk dapat menghadapi persaingan dari pemilik mebel lainnya.

\section{KESIMPULAN DAN SARAN}

\section{Kesimpulan}

Berdasarkan hasil penelitian yang telah dibahas pada bab sebelumnya, maka dapat disimpulkan. Perilaku kemandirian yang ditunjukkan oleh pengusaha mebel di Desa Suco Kecamatan Mumbulsari Kabupaten Jember meliputi sikap mandiri pemilik usaha mebel dalam mengatasi masalah dilakukan sendiri, dan upaya pemilik usaha mebel dalam memasarkan produk mebel yang juga dilakukan sendiri dengan dibantu oleh beberapa karyawan. Untuk perilaku berani menanggung resiko yang ditunjukkan oleh pengusaha mebel di Desa Suco Kecamatan Mumbulsari Kabupaten Jember meliputi upaya pemilik usaha mebel dalam melakukan pinjaman kredit guna menambah modal usaha, berupaya untuk tetap membeli bahan baku yang berkualitas walaupun dengan harga tinggi, bersedia mengganti barang yang rusak pada saat pengiriman barang, dan melakukan berbagai upaya seperti memberi potongan harga terhadap produk lama yang masih belum laku.

Perilaku bekerja keras yang ditunjukkan oleh pengusaha mebel di Desa Suco Kecamatan Mumbulsari Kabupaten Jember meliputi bekerja keras dalam hal menjalankan usaha mulai dalam pembelian bahan baku, proses produksi, sampai saat pemasaran pemilik mebel berupaya keras dalam melaksanakan hal tersebut. Bahkan pemilik usaha mebel melakukan berbagai promosi seperi pemasangan spanduk terhadap beberapa produk baru yang ada pada mebel tersebut. Dan untuk pemikiran kreatif dan inovatif yang dilakukan oleh pengusaha mebel di Desa Suco Kecamatan Mumbulsari Kabupaten Jember meliputi selalu memperbarui atau meng-update model-model, menghasilkan beberapa macam produk yang banyak dan bervariasi, memperbarui tampilan atau model beberapa produk yang masih belum terjual, dan menerima pemesanan bentuk barang sesuai dengan keinginan konsumen.

\section{Saran}

Selama melakukan pengamatan dan wawancara, umumnya para pengusaha mebel melakukan usahanya dengan pengelolaan yang sederhana, artinya tidak menggunakan pengelolaan yang berdasarkan manajemen modern seperti ada pembukuan yang canggih, pemasaran yang menggunakan prinsip modern atau pelayanan yang cukup maju.

Dengan memperhatikan perkembangan usaha mereka yang makin maju, diperlukan berbagai upaya agar usaha mebel ini dapat berkembang untuk meningkatkan kesejahteraan masyarakat. Berbagai pihak seperti pemerintah daerah Kabupaten Jember, Pemerintah Desa 
Suco dan lembaga lain dapat melakukan pendidikan manajemen usaha yang lebih baik, pelatihan-pelatihan pembukuan keuangan, pelatihan berwirausaha yang maju, penataan tempat agar lebih rapi dan teratur dan lainnya sehingga usaha mebel di Desa Suco dapat berkembang menjadi pusat mebel di Kabupaten Jember.

\section{DAFTAR BACAAN}

Alma, B. 2006. Kewirausahaan. Bandung: Alfabeta.

Astamoen, M. 2005. Entrepreneurship. Bandung: Alfabet

Hakim, R. 1998. Dengan Wiraswasta Menepis Krisis (Konsep Pembangunan Masyarakat Intrepeneur Indonesia). Jakarta : PT Elex Media Komputindo.

Kasmir. 2007. Kewirausahaan. Jakarta: PT Grafindo Persada.

Meredith, G. ed. Al. 2000. Kewiraswastaan Teori dan Praktek. Jakarta: PT. Pustaka

Binawan Pressindo.

Moleong, L.J. 2001. MetodePenelitianKualitatif. Bandung: PT Rosdakarya.

Purnomo, B.H. 2005. Membangun Semangat Kewirausahaan. Yogyakarta: Laks

Bang Pressindo

Suryana. 2006. Kewirausahaan, Pedoman Praktis: Kiat dan Proses Menuju Sukses. Jakarta: Salemba Empat.

Suparyanto. 2012. Konsep Dukungan Keluarga. http://konsep-dukungankeluarga.blogspot.com. (diunduh pada tanggal 20 Oktober 2016). 